\title{
RECEPTOR MEDIATED GONADOTROPIN ACTION IN GONADAL TISSUES: RELATIONSHIP BETWEEN BLOOD CHOLESTEROL LEVELS AND GONADOTROPIN STIMULATED STEROIDOGENESIS IN ISOLATED RAT LEYDIG AND LUTEAL CELLS*
}

\author{
Salman Azhart and K. M. J. Menonł \\ Endocrine Laboratory, Departments of Obstetrics and Gynecology and Biological Chemistry. \\ The University of Michigan Medical School. Ann Arbor, MI 48109, U.S.A.
}

(Received 7 January 1981)

\begin{abstract}
SUMMARY
The present studies were performed to evaluate the role of steroid precursors and plasma lipoproteins in gonadal tissue steroidogenesis. Leydig cell suspension isolated from rat testes responded to $h C G$. $\mathrm{Bt}_{2} \mathrm{CAMP}, 8 \mathrm{Br}$-cAMP and cholera toxin with an increase in testosterone response. Administration of 4-aminopyrazolo[3.4-d]pyrimidine (4-APP) reduced the plasma cholesterol and testosterone levels in a time and dose dependent manner. This treatment also reduced the steroidogenic capacity of isolated Leydig cells both under basal conditions and in response to trophic hormone. Different doses of 4-APP up to $25 \mathrm{mg} / \mathrm{kg} \mathrm{BW}$ and up to 4 days of treatment. however, did not modulate cholesterol and cholesterol ester contents of isolated Leydig cells. 4-APP treatment also had no effect on testis weight, phospholipid content, protein synthesis and energy metabolism in isolated Leydig cells. Similarly, administration of 4-APP $(12.5 \mathrm{mg} / \mathrm{kg})$ to PMSG-hCG primed rats beginning on day 3, post hCG, drastically reduced the circulating cholesterol and progesterone levels. Injection of the drug also produced an inhibition in in vitro luteal cell steroidogenesis and a reduction in cellular cholesterol esters and free cholesterol contents. Addition of LDL or HDL to incubation medium reversed the inhibitory effect of 4-APP on luteal cell steroidogenesis while this inhibition persisted in Leydig cells. Injection of rats with Triton-WR-1339 (mg/kg BW) resulted in a 10-fold increase in plasma cholesterol and a contrasting decrease in testosterone levels. This treatment, however, produced no effect on in vitro Leydig cell steroidogenesis or cellular content of cholesterol esters and free cholesterol. It appears that the Leydig and luteal cells process and utilize lipoprotein-delivered cholesterol for steroidogenesis through different mechanism(s). These studies thus demonstrate differential actions and an acute regulatory role of lipoproteins in gonadotropin modulated steroidogenesis in two different gonadal tissue.
\end{abstract}

\section{INTRODUCTION}

The pituitary gonadotropins are the major regulators of steroidogenesis in gonadal tissues [1-5]. In recent years considerable progress has been made in delineating the mode of action of gonadotropins ( $\mathrm{LH} / \mathrm{hCG}$ ) in target tissues [1-5]. Initial events in $\mathrm{LH} / \mathrm{hCG}$ action, including hormone receptor interaction, adenylate cyclase activation and protein kinase stimulation have been extensively studied. However, the role that the steroid precursor, cholesterol, plays in the regulation of steroidogenesis has remained relatively unexplored. The fact that in gonadal tissues, cholesterol is not only utilized for membrane biogenesis but also serves as steroid precursor, suggests that its synthesis and availability could be an important factor in the regulation of steroidogenesis.

* This work was supported by Grant No. HDO6656 from the National Institutes of Health.

+ Dr Azhar's present address is: GRECC-182B, Veterans Administration Medical Center, 3801 Miranda Avenue, Palo Alto, CA 94304, U.S.A.

¥ To whom correspondence should be addressed.
Recently, many investigators have demonstrated in the adrenal gland a close correlation between exogenous vs endogenous cholesterol levels and the extent of tissue steroidogenesis [6-14]. In contrast, to date, very limited information is available regarding the role of exogenous vs endogenous cholesterol in the regulation of gonadal tissue steroidogenesis $[6,8,15-17]$. Further, although the steroidogenic tissues, adrenal, testis, ovary, and placenta all secrete steroid, the regulatory role exerted by cholesterol could be entirely different in each of these systems.

In the present studies, attempts were made to analyze systematically the effect of varying the plasma cholesterol levels on testicular cholesterol ester and free cholesterol content and the extent of gonadotropin induced steroidogenesis in isolated Leydig cells. This was accomplished by treating rats with 4-aminopyrazolo[3,4-d]pyrimidine (4-APP) to lower the plasma lipoprotein and cholesterol levels $[18,19]$ and by injection of Triton WR-1339 to raise the circulating levels of cholesterol [20-22]. Further, attempts were also made to compare the cholesterol require- 
ments and lipoprotein utilization by ovarian (luteal) and testicular (Leydig) cells in gonadotropin induced steroidogenesis. These studies demonstrate that the two gonadal tissues exhibit considerable variation in their cholesterol requirements for gonadotropin induced steroidogenesis.

\section{MATERIALS AND METHODS}

\section{Materials}

Human chorionic gonadotropin (hCG, CR-119, $11,500 \mathrm{IU} / \mathrm{mg}$ ) was generously supplied by Dr R. Canfield, Columbia University, New York, through Population Research Branch, National Institutes of Health, Bethesda, MD. 4-Amino-pyrazolo[3,4-d]pyrimidine (4-APP) and 1 methyl-3-isobutylxanthine (MIX) were obtained from Aldrich Chemical Co., Milwaukee, WI. Collagenase (CLS) Type I and deoxyribonuclease I were purchased from Worthington Biochemical Corp., Freehold, NJ. Cholera enterotoxin and pregnant mare's serum gonadotropin (PMSG) were supplied by Schwarz/Mann and Organon OSS, Holland, respectively. 8 bromo-cyclic 3,5 adenosine monophosphate (8 Br-cAMP). Triton WR-1339 (Toxapol) and partially purified human chorionic gonadotropin (hCG) were the products of Sigma Chemical Co., St. Louis, MO. Eagle's Minimum Essential Medium with Earle's salt, Medium 199 and Medium 109 were pur. chased from Grand Island Biological Co., Grand Island, NY. ${ }^{125}$ I-choriogonadotropin was prepared according to Catt et al.[23].

\section{Isolation of Leydig cells from rat testis}

Lcydig cells from rat testis were prepared by a combination of procedures of Dufau et al.[24] and Moyle and Ramachandran[25]. Testes from 50-60-day old Sprague-Dawley rats were excised free of fat and decapsulated. Groups of four decapsulated testes were added to $50 \mathrm{ml}$ conical polypropylene centrifuge tube containing $10 \mathrm{ml}$ Medium $199,1 \mathrm{mg} / \mathrm{ml}$ bovine serum albumin (BSA) and $0.25 \mathrm{mg} / \mathrm{ml}$ collagenase (Type I). The tubes were gassed with $\mathrm{O}_{2} / \mathrm{CO}_{2}(95 / 5 \% \mathrm{v} / \mathrm{v})$. tightly capped, placed sideways in Dubonoff metabolic shaker and shaken at 100 cycles $/ \mathrm{min}$ for $20 \mathrm{~min}$ at $37^{\circ} \mathrm{C}$. At the end of incubation the tubes were filled to $40 \mathrm{ml}$ mark with Medium 199-0.1\% BSA, and gently inverted several times to facilitate the separation of interstitial cells from the tubular mass. The tubules were allowed to settle for $10 \mathrm{~min}$, and the turbid supernatant containing Leydig cells was carefully removed with a plastic disposable syringe attached to Tygon tubing. The sedimented tubular mass was washed once with $50 \mathrm{ml}$ of the same medium and after allowing the tubes to remain for $10 \mathrm{~min}$, the supernatant was carefully removed. Both supernatants were combined and Leydig cells were sedimented at $1000 \mathrm{~g}$ for $15 \mathrm{~min}$. The sedimented cells were washed two times in Medium 199-0.1\% BSA and finally resuspended in a desired volume of the same medium.

\section{Incubation conditions for testosterone production}

Rat Leydig cell suspensions $(0.1 \mathrm{ml})$, were incubated in triplicate in a final volume of $1 \mathrm{ml}$ of Medium 199 containing $0.1 \mathrm{mM}$ methyl-3-isobutylxanthine. $1 \mathrm{mg} / \mathrm{ml} \mathrm{BSA}$ and $20 \mathrm{ng} / \mathrm{ml} \mathrm{hCG}$ and/or various lipoprotein fractions. After incubation, usually for $3 \mathrm{~h}$ at $37^{\circ} \mathrm{C}$ in an atmosphere of $\mathrm{O}_{2}: \mathrm{CO}_{2}\left(95: 5^{\circ} \mathrm{v} / \mathrm{v}\right)$, the reaction was stopped by placing the sample tubes in a boiling water bath for $3 \mathrm{~min}$. Water $(1 \mathrm{ml})$ and [1,2,6.7. $\left.{ }^{3} \mathrm{H}(\mathrm{N})\right]$-testosterone (SA $98.8 \mathrm{Ci} / \mathrm{mmol}$, New England Nuclear) $(10 \mu \mathrm{l}, 10,000 \mathrm{c.p.m}$. to monitor testosterone recovery) were added and the samples left in the cold overnight. The next morning the samples were extracted with anhydrous diethyl ether [26] and assayed for testosterone by radioimmunoassay as described by Niswender et al.[27].

\section{Binding of $\left[{ }^{125} I\right]-h C G$ to testis Leydig cells}

Incubation in a final volume of $1 \mathrm{ml}$ Medium 199 contained the testis Leydig cells suspension, $1 \mathrm{mg} / \mathrm{ml}$ BSA, [ $\left.{ }^{125} \mathrm{I}\right]-\mathrm{hCG} \quad(200,000$ c.p.m., 5-10 ng) and increasing amounts of unlabeled $\mathrm{hCG}$. After incubation at $37^{\circ} \mathrm{C}$ for $2 \mathrm{~h}$ in the presence of $\mathrm{O}_{2}: \mathrm{CO}_{2}$ $(95: 5 \mathrm{v} / \mathrm{v}), 2 \mathrm{ml}$ ice cold medium was added and tubes were centrifuged at $100 \mathrm{~g}$ for $15 \mathrm{~min}$ in the cold. The pellets were washed once with $2 \mathrm{ml}$ medium and counted for radioactivity in a gamma counter (Searle). The specific binding was calculated from the difference of total binding to that observed in the presence of 1000 -fold excess unlabeled hCG.

\section{Hormonal treatment of female rats}

Twenty-two to twenty-four day old female Sprague-Dawley rats (Spartan Research. Inc., Hazlett. MI) were used in the present studies. Highly luteinized ovaries from these rats were obtained following a regimen described by Parlow[28]. Rats were injected subcutaneously with $50 \mathrm{IU}$ of PMSG and followed $56 \mathrm{~h}$ later with $25 \mathrm{IU}$ of hCG (Sigma). Day 0 was taken as the day of hCG injection.

\section{Preparation of collagenase-dispersed luteal cells}

The collagenase dispersed luteal cells were prepared by the procedure described earlier from this laboratory $[29,30]$.

\section{Incubation conditions for progesterone mcasurement}

Luteal cells $\left(1.5\right.$ to $\left.2 \times 10^{6}\right)$ were incubated in $0.4 \mathrm{ml}$ of Medium 109 containing $1 \mathrm{mg} / \mathrm{ml} \mathrm{BSA}$, and where required, $10 \mathrm{ng} / \mathrm{ml} \mathrm{hCG}$ and/or appropriate concentrations of lipoprotein fractions were also added. The incubations were performed at $37^{\circ} \mathrm{C}$ in a Dubnoff metabolic shaking water bath gassed with $\mathrm{O}_{2}: \mathrm{CO}_{2}(95: 5 \mathrm{v} / \mathrm{v})$. Following incubation, the reaction was stopped by placing the tubes in a boiling water bath for $3 \mathrm{~min}$. Water $(0.5 \mathrm{ml})$ and $\left[1,2-{ }^{3} \mathrm{H}(\mathrm{N})\right]-$ progesterone (SA $55 \mathrm{Ci} / \mathrm{mmol})(10 \mu \mathrm{l}, 10,000$ c.p.m. to monitor progesterone recovery) were added and the samples left in the cold overnight. The next day 

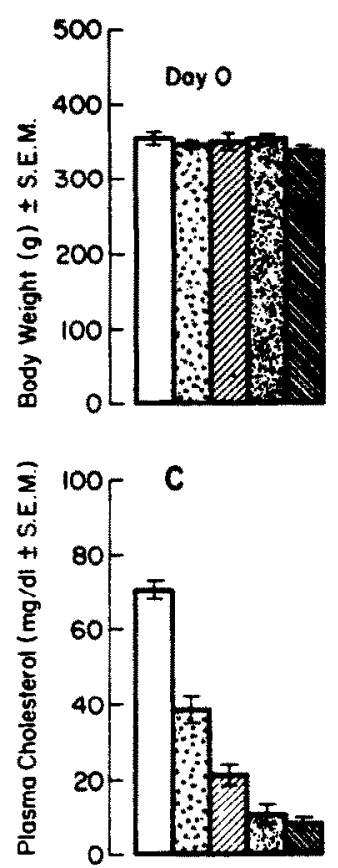

A
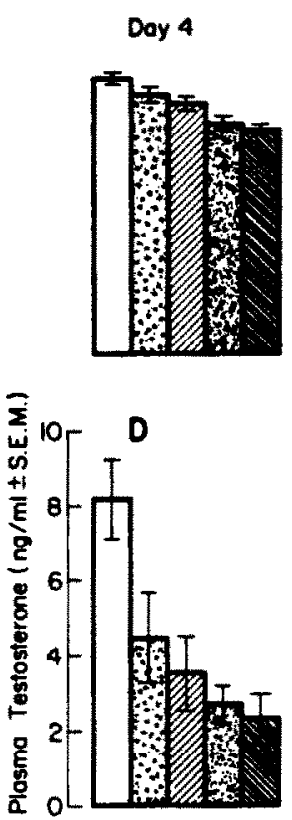

B

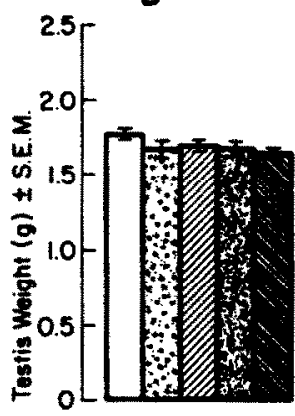

Fig. 1. Effect of injection of different doses of 4-APP on body weight, testis weight, plasma cholesterol, testosterone and free and esterified cholesterol contents in isolated Leydig cell suspension. Groups of four male rats (50-60-day old) were injected with phosphate buffered saline (PBS pH 4.0) or indicated doses of 4-APP every day for 3 days. On the fourth day rats were weighed for body weight and then killed. The pooled testes from each group were processed for the isolation of Leydig cell suspension by collagenase treatment as described in "Materials and Methods" The free cholesterol and choisterol ester content of Leydig cells were separated by silicic acid/celite column chromatography.

samples were extracted with light petroleum ether and assayed for progesterone by radioimmunoassay as described previously $[31,32]$.

\section{Analytical procedures}

DNA content of the cells was measured by the colorimetric procedure of Burton[33]. Total plasma or serum cholesterol was determined by the procedure of Zak[34]. Cellular free cholesterol and cholesterol esters were separated according to the procedure of Brown et al.[35]. Cholesterol esters after saponification in alcoholic $\mathrm{KOH}$ and free cholesterol were quantitated by the micromethod of Glick et al.[36]. Human plasma LDL (d, 1.019-1.063 g/ml) and $\mathrm{HDL}(\mathrm{d}, 1.09-1.215 \mathrm{~g} / \mathrm{ml})$ were isolated by differential ultracentrifugation using $\mathrm{KBr}$ for density adjustment [37]. Isolated lipoprotein fractions weredialyzed for $36-48 \mathrm{~h}$ against three to four changes of $0.15 \mathrm{M} \mathrm{NaCl}$ containing $0.3 \mathrm{mM}$ EDTA. Before use, these fractions were dialyzed against $0.15 \mathrm{M} \mathrm{NaCl}$ to remove EDTA. Purity of lipoprotein fractions was checked by agarose gel electrophoresis in $0.05 \mathrm{M}$ barbital buffer pH 6.8 using precast (Bio-Gram A, BioRad) agarose slides. The mass ratio of total cholesterol to protein was $1.4: 1$ and $1: 3.58$ for LDL and HDL, respectively. Protein content of lipoproteins was determined by a modification of the procedure of Lowry et al.[38] as described by Markwell et al.[39].

\section{RESULTS}

Effect of different doses of 4-APP injection on plasma cholesterol, testosterone levels and testicular cell cholesterol and sterol ester contents

As shown in Fig. 1, injection of 4-APP at a dose of $12.5 \mathrm{mg} / \mathrm{kg} \mathrm{BW}$ or $25 \mathrm{mg} / \mathrm{kg}$ BW slightly but significantly reduced the body weight. 4-APP treatment, however, produced no significant effect on testis weight. Injection of different doses of 4-APP (3.08, $6.25,12.5$ and $25 \mathrm{mg} / \mathrm{kg} \mathrm{BW}$ ) also reduced the plasma cholesterol and testosterone levels in a dose dependent manner (Fig. 1). In contrast, cholesterol and sterol ester contents of interstitial (Leydig) cells were not affected by 4APP treatment.

Effect of increasing doses of 4-APP injection on in vitro steroidogenesis in isolated Leydig cell suspension

Injection of low dose of 4 APP ( $3.08 \mathrm{mg} / \mathrm{kg} \mathrm{BW}$ ) to rats caused a significant inhibition in basal as well as hCG, $8 \mathrm{Br}$-cAMP and cholera toxin stimulated steroid production in isolated Leydig cells (Table 1). Increasing the 4-APP dose to $6.25 \mathrm{mg} / \mathrm{kg} \mathrm{BW}$ further reduced the steroidogenic capacity of isolated Leydig cells both under basal condition and in response to various stimulators. Maximum inhibition of basal and hormone-stimulated in vitro steroidogenesis was observed when rats were pretreated with 4-APP at a 
Table 1. Effect of different doses of 4-APP injection on hCG, cholera toxin and $8 \mathrm{Br}$-cAMP stimulated steroidogenesis in isolated Leydig cells

\begin{tabular}{ccccc}
\hline $\begin{array}{c}4-A P P \\
(\mathrm{mg} / \mathrm{kg} \mathrm{BW})\end{array}$ & Basal & $\begin{array}{c}\left.\text { Testosterone (pg } \mu \mathrm{gNA}^{-1} \pm \mathrm{SEM}\right) \\
\text { hCG } \\
(20 \mathrm{ng} / \mathrm{ml})\end{array}$ & $\begin{array}{c}\text { Br-cAMP } \\
(1.5 \mathrm{mM})\end{array}$ & $\begin{array}{c}\text { Cholera toxin } \\
(1 \mu \mathrm{g} / \mathrm{ml})\end{array}$ \\
\hline 0 & $181 \pm 10$ & $1070 \pm 30$ & $1100 \pm 31$ & $430 \pm 38$ \\
3.08 & $152 \pm 6$ & $787 \pm 60$ & $730 \pm 6$ & $320 \pm 9$ \\
6.25 & $108 \pm 10$ & $584 \pm 43$ & $710 \pm 31$ & $340 \pm 15$ \\
12.50 & $77 \pm 7$ & $550 \pm 35$ & $620 \pm 37$ & $289 \pm 29$ \\
25 & $95 \pm 10$ & $570 \pm 64$ & $640 \pm 33$ & $280 \pm 18$ \\
\hline
\end{tabular}

Groups of four rats were injected with indicated doses of 4-APP every $4 \mathrm{~h}$ for 3 days and rats were killed on day 4 . The testes were treated with collagenase for the isolation of crude Leydig cell suspension. The isolated cells were incubated for $3 \mathrm{~h}$ with hCG, $8 \mathrm{Br}$-cAMP or cholera toxin as described in "Materials and Methods." After the incubation, samples (medium + cells) were extracted and assayed for testosterone by radioimmunoassay. The results are mean of three different experiments.

dose of $12.5 \mathrm{mg} / \mathrm{kg} \mathrm{BW}$. In subsequent experiments rats were injected with this dose of 4-APP $(12.5 \mathrm{mg} / \mathrm{kg} \mathrm{BW})$ to reduce the circulating levels of cholesterol and to monitor the effect on in vitro steroidogenesis under variable physiological conditions.

\section{Time dependent effect of 4-APP treatment}

Results presented in Fig. 2 and Table 2 demon-
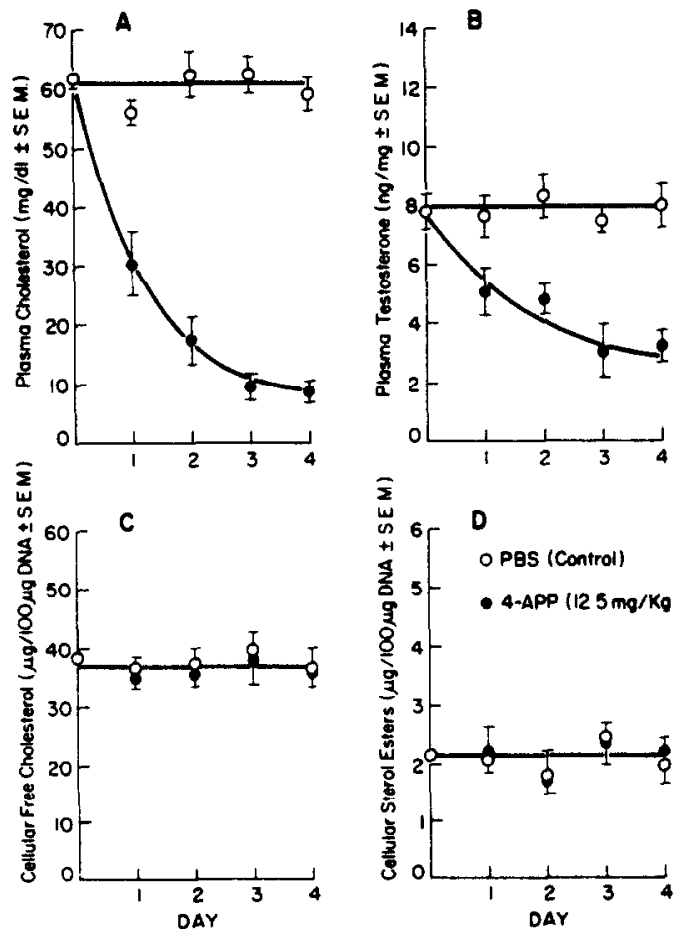

Fig. 2. Effect of varying 4-APP injection time on plasma cholesterol, plasma testosterone. Leydig cell free cholesterol and cholesterol ester contents. Groups (6) of 50-60-day old rats were injected with PBS or 4-APP $(12.5 \mathrm{mg} / \mathrm{kg}$ BW) every day for 4 days. After $24 \mathrm{~h}$ following last injection, the rats were killed and plasma cholesterol and testosterone measurements were made using plasma of collected blood. Leydig cell isolation and separation of cellular cholesterol and cholesterol ester content were carried out as described in "Materials and Methods." strate time-dependent effect of 4-APP $(12.5 \mathrm{mg} / \mathrm{kg}$ BW) injection on plasma cholesterol, testosterone and Leydig cell steroidogenesis and sterol contents. Drug treatment resulted in a 50\% decrease in plasma cholesterol levels after 1 day of injection and by 2 days the cholesterol levels were reduced to $25 \%$ of control values. Cholesterol was maximally reduced $(85 \%)$ between days 3 and 4 . Similarly, 4-APP treatment decreased serum testosterone levels approximately 40 and $50 \%$ on day 1 and day 2 after the injection. Maximum decrease in testosterone levels was observed on days 3 and 4 . In contrast, cellular cholesterol and cholesterol ester contents remained unchanged following 4-APP injection (Fig. 2). Leydig cell suspension prepared from 4-APP injected rats exhibited ap-

Table 2. Time-dependent effect of 4-APP injection on in citro steroidogenesis in isolated Leydig cells

\begin{tabular}{|c|c|c|}
\hline & $\begin{array}{c}\text { Testosterone } \\
\text { Basal }\end{array}$ & $\begin{array}{c}\left.\mathrm{NA}^{-1} \pm \mathrm{SEM}\right) \\
\mathrm{hCG} \\
(20 \mathrm{ng} / \mathrm{ml})\end{array}$ \\
\hline $\begin{array}{l}\text { Day } 1 \\
\text { PBS } \\
\text { 4-APP }\end{array}$ & $\begin{array}{l}175 \pm 7 \\
192 \pm 39\end{array}$ & $\begin{array}{l}831 \pm 45 \\
784 \pm 41\end{array}$ \\
\hline $\begin{array}{l}\text { Day } 2 \\
\text { PBS } \\
4 \text { APP }\end{array}$ & $\begin{array}{c}197 \pm 11 \\
99 \pm 4\end{array}$ & $\begin{array}{l}872 \pm 53 \\
456 \pm 22\end{array}$ \\
\hline $\begin{array}{l}\text { Day } 3 \\
\text { PBS } \\
\text { 4-APP }\end{array}$ & $\begin{array}{l}204 \pm 39 \\
120 \pm 25\end{array}$ & $\begin{array}{r}1083 \pm 64 \\
559 \pm 13\end{array}$ \\
\hline $\begin{array}{l}\text { Day } 4 \\
\text { PBS } \\
\text { 4-APP }\end{array}$ & $\begin{array}{r}185 \pm 21 \\
87 \pm 32\end{array}$ & $\begin{array}{r}1400 \pm 19 \\
730 \pm 59\end{array}$ \\
\hline
\end{tabular}

Groups of rats were injected with saline or 4-APP $(12.5 \mathrm{mg} / \mathrm{kg} \mathrm{BW})$ every $24 \mathrm{~h}$ for up to 4 days. Rats were killed on day 1, 2,3 and 4. The testes were removed, decapsulated, and interstitial (Leydig cell) suspensions were prepared by collagenase digestion. Aliquots of isolated cells were incubated with or without hCG $(20 \mathrm{ng} / \mathrm{ml})$ and in citro testosterone production was followed for $3 \mathrm{~h}$. The results are mean of three different experiments. 
Table 3. Time-dependent effect of 4-APP injection on [125I]-hCG binding to isolated Leydig cell suspension

\begin{tabular}{cc}
\hline $\begin{array}{c}\text { 4-APP (12.5 mg/kg BW) } \\
\text { Treatment }\end{array}$ & $\begin{array}{c}{\left[{ }^{125} \mathrm{I}\right]-\mathrm{hCG} \text { Binding* }} \\
(\% \text { of control) }\end{array}$ \\
\hline Day 1 & 73.3 \\
Day 2 & 64.9 \\
Day 3 & 60.8 \\
Day 4 & 53.9 \\
\hline
\end{tabular}

Experimental details were the same described in "Materials and Methods."

* Results are mean of three separate experiments.

proximately $50 \%$ inhibition in basal and hCG stimulated testosterone production compared to cells from saline injected rats. The inhibitory effect of 4-APP was first observed after two days of drug injection, and the effect persisted and remained unchanged after 3 and 4 days of injection (Table 2). Surprisingly, 4-APP treatment also produced a significant inhibition in gonadotropin $\left({ }^{125} \mathrm{I}-\mathrm{hCG}\right)$ binding to Leydig cells (Table 3 ).

Effect of lipoprotein additions on in vitro steroidogenesis by Leydig and luteal cells obtained from 4-APP injected rats

Results presented in Fig. 3 demonstrate the effect of 4-APP injection on plasma testosterone and pro- gesterone levels in male and pseudopregnant female rats. As shown in Fig. 1 and also in Fig. 3, injection of 4APP $(12.5 \mathrm{mg} / \mathrm{kg} \mathrm{BW})$ for 3 days significantly decreased the plasma cholesterol and testosterone levels in male rats. Similarly in pseudopregnant female rats, 4-APP injection drastically reduced the plasma progesterone and cholesterol levels. The in vivo treatment of pseudopregnant rats with 4-APP resulted in signifcant inhibition of basal and hCG stimulated steroidogenesis in isolated luteal cells (Fig. 3). Addition of h-LDL (750 $\mu \mathrm{g}$ protein $/ \mathrm{ml})$ or h-HDL $(700 \mu \mathrm{g}$ protein $/ \mathrm{ml}$ ) to luteal cells isolated from PBS injected rats caused about 2-fold increase in basal progesterone production and both lipoproteins greatly potentiated the gonadotropin-stimulated steroid production. Interestingly, addition of $\mathrm{h}-\mathrm{LDL}$ to luteal cells from 4-APP injected rats completely reversed the inhibitory action of the drug on hCG-stimulated progesterone accumulation. $h-L D L$ also partially reversed the inhibition of basal steroid production seen in luteal cells of 4-APP injected rats. h-HDL, although producing identical effects, was slightly less effective than h-LDL. In contrast, neither h-LDL nor h-HDL was able to overcome the inhibitory effect of 4-APP seen in Leydig cell steroidogenesis (Fig. 3). Further, compared to its lack of effect on Leydig cell cholesterol and cholesterol ester contents (Fig. 1 and 2), injection of the drug 4-APP to pseudopregnant rats
A

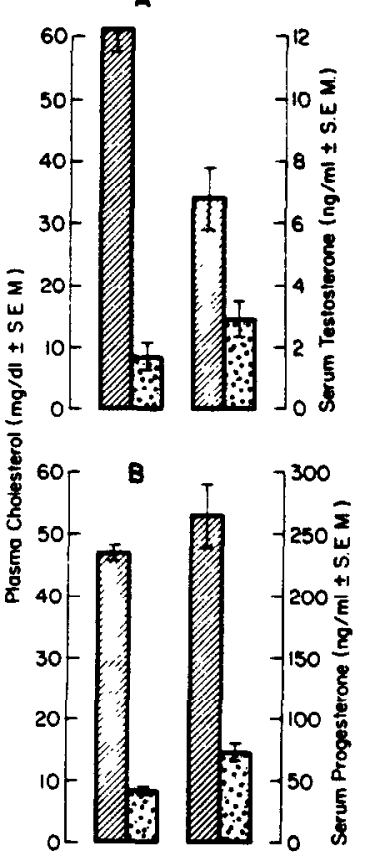

C
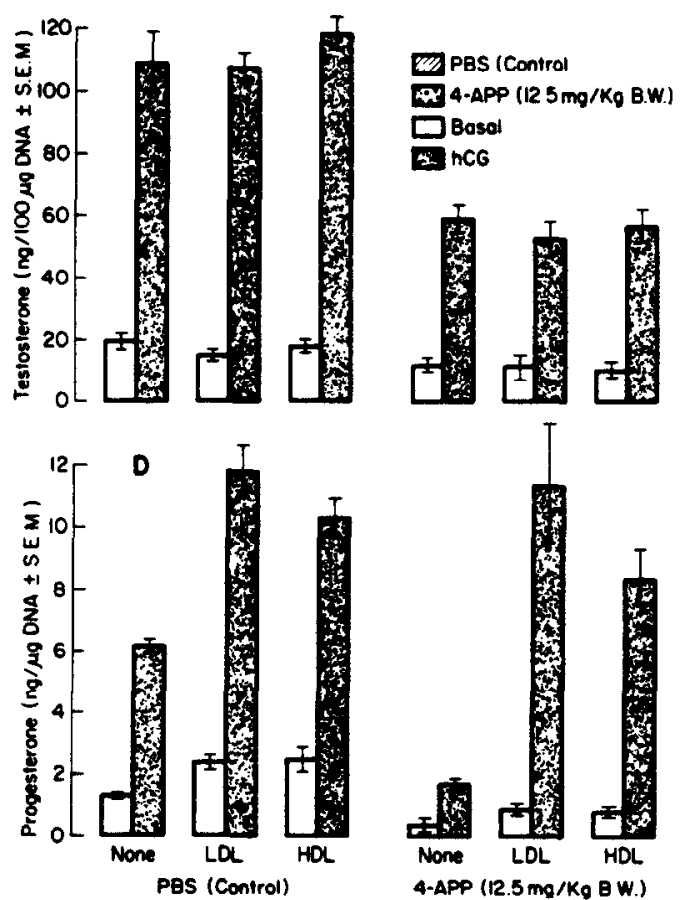

Fig. 3. Effect of 4-APP injection to male rats or pseudopregnant rats on steroidogenesis in isolated cells in response to gonadotropins and lipoproteins. Pseudopregnancy in 23-day old rats was induced by injection of 50 IU PMSG followed $56 \mathrm{~h}$ later with a single injection of $25 \mathrm{IU}$ hCG (day 0). On day 3 PBS or 4 APP $(12.5 \mathrm{mg} / \mathrm{kg} \mathrm{BW})$ were injected every day for 3 days. Similarly, male rats were injected with PBS or 4-APP every day for 3 days. Twenty-four hours after last injection, Leydig cells and luteal cells from testes and luteinized ovaries, respectively, were isolated and incubated with lipoproteins and/or hCG for steroid production. Testosterone and progesterone on extracted samples were assayed by specific radioimmunoassays. $A$ and $C$ refer to males and $B$ and $D$ to females. 


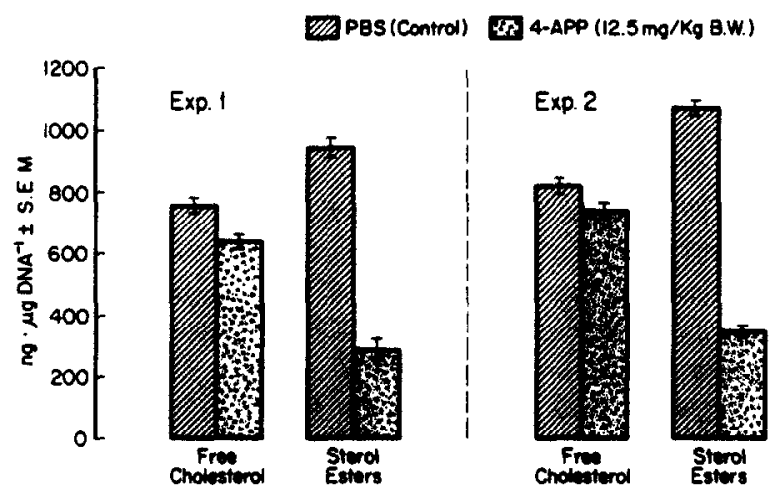

Fig. 4. Effect of 4-APP injection to pseudopregnant rats on cholesterol and cholesterol ester contents in luteal cells. Groups (4) of rats were injected with PBS or 4-APP $(12.5 \mathrm{mg} / \mathrm{kg} \mathrm{BW})$ as described in Fig. 3. Cholesterol and cholesterol ester from luteal cells were separated by silicic acid/celite column chromatography.

caused a $60-70 \%$ decrease in cholesterol ester content and a slight but significant reduction in free cholesterol levels in luteal cells (Fig. 4).

\section{Effect of Triton WR-1339 injection}

Further experiments were performed to monitor the effect of raising plasma cholesterol levels on Leydig cell steroidogenesis. This was accomplished by
Table 4. Effect of Triton-Wr-1339 injection on $\left[{ }^{123} \mathrm{I}\right]-\mathrm{hCG}$ binding to isolated Leydig cell suspension

\begin{tabular}{cc}
\hline $\begin{array}{c}\text { Days after Triton } \\
\text { Wr-1339 injection }\end{array}$ & $\begin{array}{r}{\left[{ }^{25} \text { I] }\right.} \\
\text { (\% } \% \text { of control) }\end{array}$ \\
\hline Day 1 & 89 \\
Day 2 & 72 \\
Day 3 & 94 \\
\hline
\end{tabular}

Groups of four rats were injected with normal saline or Triton WR-1339 $(1 \mathrm{~g} / \mathrm{kg} \mathrm{BW})$ every $12 \mathrm{~h}$ for 1,2 and 3 days and killed $12 \mathrm{~h}$ after last injection. [ $\left.{ }^{125} \mathrm{I}\right]-\mathrm{hCG}$ binding to isolated Leydig cell suspension was carried out as described in "Materials and Methods." Results are mean of four difierent experiments.

treating rats with Triton WR-1339, a pharmacological agent known to increase circulating cholesterol levels [20-22]. Results presented in Fig. 5 demon. strate that treatment of rats with Triton WR-1339 caused a 6-fold increase in plasma cholesterol levels after one day of detergent injection. The maximum increase in plasma cholesterol (10-11-fold) levels was observed after 2 days of treatment and then remained elevated up to 3 days. In contrast, Triton WR-1339 injection caused a maximum reduction in plasma
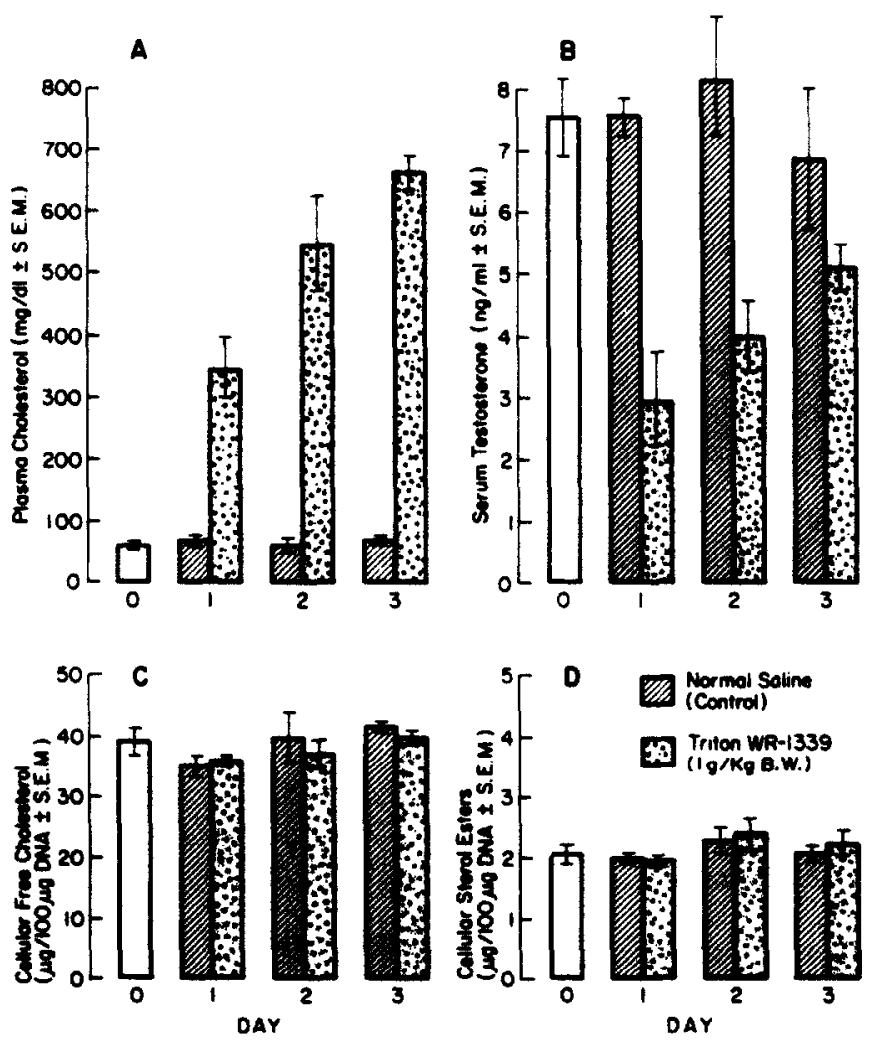

Fig. 5. Effect of varying Triton WR-1339 injection time on plasma cholesterol and testosterone levels and Leydig cell cholesterol and sterol ester contents. Groups of four rats (50-60-day old rats) were injected with normal saline or Triton-Wr-1339 (lg/kg BW) every $12 \mathrm{~h}$ for 1,2 or 3 days. After $12 \mathrm{~h}$ following last injection, plasma cholesterol, testosterone and Leydig cell free cholesterol and sterol esters were measured as described in "Materials and Methods." 
Table 5. Effect of Triton WR-1339 injection on in vitro steroidogenesis in isolated Leydig cell suspension

\begin{tabular}{|c|c|c|c|c|c|c|}
\hline $\begin{array}{l}\text { Treatment } \\
\text { (days) }\end{array}$ & Basal & $\begin{array}{r}\text { Test } \\
\text { hCG } \\
(20 \mathrm{ng} / \mathrm{ml})\end{array}$ & $\begin{array}{c}\text { sterone (pg } \mu \\
\text { h-LDL } \\
(750 \mu \mathrm{g} \\
\text { protein } / \mathrm{ml})\end{array}$ & 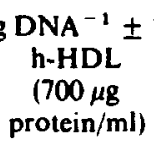 & $\begin{array}{c}\text { h-LDL } \\
+ \\
\text { hCG }\end{array}$ & $\begin{array}{c}\text { h-HDL } \\
+ \\
\text { hCG }\end{array}$ \\
\hline $\begin{array}{l}\text { Dayl } \\
\text { Saline } \\
\text { Triton }\end{array}$ & $\begin{array}{l}172 \pm 9 \\
188 \pm 12\end{array}$ & $\begin{array}{l}1400 \pm 84 \\
1540 \pm 160\end{array}$ & $\begin{array}{l}220 \pm 23 \\
220 \pm 17\end{array}$ & $\begin{array}{l}239 \pm 16 \\
181 \pm 16\end{array}$ & $\begin{array}{l}1310 \pm 22 \\
1270 \pm 180\end{array}$ & $\begin{array}{l}1290 \pm 33 \\
1310 \pm 210\end{array}$ \\
\hline $\begin{array}{l}\text { Day } 2 \\
\text { Saline } \\
\text { Triton }\end{array}$ & $\begin{array}{l}176 \pm 17 \\
163 \pm 5\end{array}$ & $\begin{array}{l}1389 \pm 104 \\
1404 \pm 170\end{array}$ & $\begin{array}{l}185 \pm 10 \\
201 \pm 40\end{array}$ & $\begin{array}{l}173 \pm 17 \\
187 \pm 43\end{array}$ & $\begin{array}{l}1435 \pm 65 \\
1395 \pm 33\end{array}$ & $\begin{array}{l}1175 \pm 210 \\
1371 \pm 81\end{array}$ \\
\hline $\begin{array}{l}\text { Day } 3 \\
\text { Saline } \\
\text { Triton }\end{array}$ & $\begin{array}{l}176 \pm 3 \\
187 \pm 9\end{array}$ & $\begin{array}{l}1300 \pm 66 \\
1346 \pm 220\end{array}$ & $\begin{aligned} 193 & \pm 13 \\
1737 & \pm 8\end{aligned}$ & $\begin{array}{l}165 \pm 7 \\
205 \pm 13\end{array}$ & $\begin{array}{l}1350 \pm 49 \\
1070 \pm 600\end{array}$ & $\begin{array}{l}1480 \pm 600 \\
1240 \pm 87\end{array}$ \\
\hline
\end{tabular}

Groups of six rats were injected with saline or Triton WR-1339 $(1 \mathrm{~g} / \mathrm{kg} \mathrm{BW})$ every $12 \mathrm{~h}$ for 1,2 or 3 days. Twenty-four hours after the last injection, the rats were killed and Leydig cells suspension were prepared by collagenase treatment as described in the "Materials and Methods". Aliquots of cells were incubated with indicated concentrations of various substnaces. After incubation for $3 \mathrm{~h}$, samples (Medium + cells) were extracted and assayed for testosterone by radioimmunoassay.

testosterone levels after day 1. Although plasma testosterone levels slightly increased on day 2 and day 3 , the drug-mediated inhibition persisted in treated groups during the entire period of experiment. Detergent treatment, however, produced no significant effect on Leydig cell cholesterol and cholesterol ester contents (Fig. 5).

In vivo treatment of rats with detergent also caused a slight decrease in [ $\left.{ }^{125} \mathrm{I}\right]$-hCG binding activity to isolated Leydig cell suspension (Table 4). Similarly, Triton treatment was without any discernable effect on steroidogenesis in isolated Leydig cell suspension (Table 5). Further addition of h-LDL or h-HDL failed to modulate steroidogenesis in Leydig cell suspension isolated from testes of rats pretreated with normal saline or Triton Wr-1339.

\section{DISCUSSION}

In the present studies, attempts were made to explore the role of circulating plasma cholesterol on gonadal steroidogenesis with special emphasis on Leydig cell steroidogenesis. The drug 4-APP, an adenine analog, has previously been reported to block secretion of all major classes of plasma lipoproteins and subsequently lead to a decrease in plasma cholesterol levels $[6,18,19,40]$. This drug was therefore selected to lower circulating plasma cholesterol levels and to monitor Leydig cell steroidogenesis in vitro and in vivo under identical experimental conditions.

Subcutaneous administration of 4APP markedly reduced the circulating levels of cholesterol in male rats in a dose and time-dependent manner. The druginduced decrease in plasma cholesterol was closely associated with a parallel decrease in plasma testosterone levels. Further, Leydig cell suspensions isolated from testes of 4-APP injected rats exhibited a de- creased steroidogenic activity both under basal conditions and also in response to trophic hormone. Although maximum testosterone production was considerably decreased in Leydig cells of 4-APP injected rats, these cells still retained the capability to respond to gonadotropins. These observations thus support the notion that the various enzymes and steps involved in testosterone synthesis are probably not affected by this treatment. Surprisingly, 4-APP treatment also slightly decreased the gonadotropin binding activity of Leydig cells. However, inhibition of gonadotropin-receptor-adenylate cyclase system by 4-APP cannot be ruled as its sole point of action, since Leydig cells also showed decreased steroidogenesis in response to $\mathrm{Bt}_{2} \mathrm{cAMP}$ and $8 \mathrm{Br}$-cAMP, agents which bypass initial steps of gonadotropin action [1-5]. Further, since in Leydig cells only about $10 \%$ receptors need to be occupied for maximum expression of steroidogensis [41], the $60-70 \%$ receptor concentration retained by cells from 4-APP injected rats should be sufficient to carry on maximum rate of testosterone synthesis. In contrast to the inhibition of steroidogenesis seen, 4-APP treatment failed to modulate the cholesterol esters and free cholesterol contents of isolated Leydig cell suspension. These results are in agreement with those reported previously by Andersen and Dietschy[8] for intact rat testis. In addition, our observations that 4-APP did not affect testes weight, phospholipid, protein synthesis and energy metabolism of Leydig cells (Azhar and Menon, unpublished observation) further rule out the possibility that the inhibitory effect of drug on steroidogenesis was due to general cytotoxic action.

Similarly Gerson et al.[42] found no change in testicular cholesterol contents following treatment of rats with $\beta$-sitosterol although this plant sterol under identical experimental conditions produced a signifi- 
cant drop in plasma cholesterol levels. Further studies by Morris and Chaikoff [43], based upon the $\left[{ }^{14} \mathrm{C}\right]$-acetate incorporation into cholesterol concluded that most of the testicular cholesterol is synthesized de novo. Although in the present studies 4-APP treatment failed to modulate testicular cholesterol and sterol ester contents, it drastically reduced the steroidogenic capacity of isolated Leydig cells. Thus, the present studies as well as in vivo studies reported by Andersen and Dietschy[8] support a regulatory role of plasma lipoproteins in testicular steroidogenesis.

Further studies were performed to see if the inhibitory action of 4APP could be reversed by the addition of various lipoproteins. The in vivo studies reported recently suggest that testes preferentially utilize HDL for steroid synthesis [8], while in adrenals cholesterol for steroidogenesis can be obtained from HDL $[6,8]$ and/or LDL [10]. The demonstration of specific receptors for HDL on testicular interstitial cell plasma membrane further suggests that Leydig cells are probably equipped with the necessary machinery to bind and metabolize the lipoproteins [44]. However, all our efforts to reverse the inhibitory action of 4-APP by in vitro lipoprotein addition were unsuccessful. Further, while 4-APP treatment leads to stimulation of de novo synthesis of cholesterol in testis [8], the amount produced probably is not sufficient to support steroidogenesis maximally. Contrary to these observations, in luteal cells the inhibitory action of 4-APP on steroidogenesis was reversed by the addition of LDL or HDL. In addition, 4APP treatment drastically reduced the cholesterol ester content in luteal cells while this treatment had no effect on Leydig cell cholesterol and cholesterol ester content. Thus, results of the present study as well as those reported by Schuler et al.[17] and Schreiber et al.[45] for granulosa cells, suggest that cells of ovarian origin can effectively utilize LDL and/or HDL delivered choiesterol for steroidogenesis, whereas in short-term incubated Leydig cells, lipoproteins probably do not support steroidogenesis. However, the possibility that during isolation Leydig cells lose their cell surface components necessary for lipoprotein binding and/or processing cannot be ruled out at present.

Injection of rats with Triton WR-1339 produced approximately 10-fold increase in plasma cholesterol, an effect observed earlier by Goldfarb[21] and Anderson and Dietschy[46]. The detergent mediated increase in plasma cholesterol levels is due to its capacity to block lipid clearance [47-50]. Although feeding high cholesterol diet could also lead to increase in serum cholesterol levels $[43,51]$ it is not clear if dietary ingested cholesterol totally gets incorporated into lipoproteins. In addition, Triton WR-1339 mediated increase in plasma cholesterol can be achieved within 2-3 days, compared to 6-12 days required for diet-induced hypercholesterolemia $[43,51]$. Finally, diet-induced hypercholesterolemia may also affect lipoprotein secretion [52]. In contrast, to increase in plasma cholesterol levels. detergent injection caused a significant inhibition in plasma testosterone levels. However. Triton WR-1339 injection did not affect the steroidogenic capacity of isolated Leydig cell suspensions either under basal conditions or in response to trophic hormone. Since we could not detect any change in cholesterol and cholesterol ester contents of Leydig cells following Triton WR-1339 injection, the inhibition of plasma testosterone could be due to a secondary effect. It is quite possible that Triton WR-1339 treatment somehow interfered with the release of LH from the pituitary and a subsequent inhibition in the in vivo testosterone production and release into the plasma.

In summary, the present studies demonstrate that reduction in plasma cholesterol levels by 4-APP treatment leads to a significant inhibition of in vitro steroidogenic capacity of gonadal cells. This inhibition of steroidogenesis in luteal cells was effectively reversed by in vitro addition of LDL or HDL. In contrast, coincubation of Leydig cells with LDL or HDL did not reverse the inhibitory action of 4-APP on testosterone synthesis. It appears, therefore, that Leydig and luteal cells probably process and utilize lipoprotein delivered cholesterol for steroidogenesis through different mechanisms.

Acknowledgements-The authors wish to thank Ms Monica Romero for her excellent technical assistance, Ms Phillipa Meyering and Helle Peegel for editorial assistance and Mrs Juanita Boldt for secretarial services.

\section{REFERENCES}

1. Catt K. J. and Dufau M. L.: Basic concepts of the mechanism of action of peptide hormones. Biol. Rep. 14, (1976) 1-15.

2. Marsh J. M.: The role of cyclic AMP in gonadal steroidogenesis. Biol. Rep. 14 (1976) 30-53.

3. Channing C. P. and Tsafriri A.: Mechanism of action of luteinizing hormone and follicle-stimulating hormone on the ovary in titro. Metabolism 26 (1977) 413-468.

4. Tell G. P., Haour F. and Saez J. M.: Hormonal regulation of membrane receptors and cell responsiveness: A review. Metabolism 27 (1978) 1566-1592.

5. Catt K. J., Harwood J. P., Clayton R. N., Davies T. F.. Chan V., Katikineni M., Nozu K. and Dufau M. L. Regulation of peptide hormone receptors and gonadol steroidogenesis. Recent Prog. horm. Res. 36 (1980) 557-622.

6. Andersen J. M. and Dietschy J. M.: Regulation of sterol synthesis in 16 tissues of rat. 11. Role of rat and human high and low density lipoproteins and of rat chylomicron remnants. J. biol. Chem. 252 (1977) 3652-3659.

7. Faust J. R., Goldstein J. L. and Brown M. S.: Receptor-mediated uptake of low density lipoprotein and utilization of its cholesterol for steroid synthesis in cultured mouse adrenal cells. J. biol. Chem. 252 (1977) 4861-4871.

8. Andersen J. M. and Dietschy J. M.: Relative importance of high and low density lipoproteins in the regulation of cholesterol synthesis in the adrenal gland. ovary and testis of the rat. J. biol. Chem. 253 (1978) $9024-9032$. 
9. Kovanen P. T., Faust J. R.. Brown M. S. and Goldstein J. L.: Low density lipoprotein receptors in bovine adrenal cortex. I. Receptor-mediated uptake of low density lipoprotein and utilization of its cholesterol for steroid synthesis in cultured adrenocortical cells. Endocrinology 104 (1979) 599-609.

10. Kovanen P. T., Schneider W. J., Hillman G. M., Goldstein J. L. and Brown M. S.: Separate mechanisms for the uptake of high and low density lipoproteins by mouse adrenal gland in vivo. J. biol. Chem. 254 (1979) 5498-5505.

11. Carr B. R., MacDonald P. C. and Simpson E. R.: The regulation of de novo synthesis of cholesterol in the human fetal adrenal gland by low density lipoprotein and adrenocorticotropin. Endocrinology 197 (1980) $1000-1006$.

12. Carr B. R., Porter J. C., MacDonald P. C. and Simpson E. R.: Metabolism of low density lipoprotein by human fetal adrenal tissue. Endocrinology 107 (1980) 1034-1040.

13. Carr B. R., Parker C. R. Jr, Milewich L., Porter J. C., MacDonald P. C. and Simpson E. R.: The role of low density, high density, and very low density lipoproteins in steroidogenesis by the human fetal adrenal gland. Endocrinology 106 (1980) 1854-1860.

14. Brown M. S., Kovanen P. T. and Goldstein J. L.: Receptor mediated uptake of lipoprotein-cholesterol and its utilization for steroid synthesis in the adrenal cortex. Recent prog. horm. Res. 35 (1979) 215-257.

15. Kovanen P. T., Goldstein J. L. and Brown M. S.: High levels of 3-hydroxy-3-methylglutaryl coenzyme A reductase activity and cholesterol synthesis in the ovary of the pregnant rabbit. J. biol. Chem. 253 (1978) 5126-5132.

16. Christie M. H., Strauss J. F. III and Flickinger G. L.: Effect of reduced blood cholesterol on sterol and steroid metabolism. Endocrinology 105 (1979) 92-98.

17. Schuler L. A., Scavo L., Kirsch T. M., Flickinger G. L. and Strauss J. F. III.: Regulation of de novo biosynthesis of cholesterol and progestins, and formation of cholesteryl ester in rat corpus luteum by exogenous sterol. J. biol. Chem. 254 (1979) 8662-8668.

18. Henderson J. F.: Studies on fatty liver induction by 4-aminopyrazolopyrimidine. J. lipid Res. 4 (1963) 68-74.

19. Shiff T. S., Roheim P. S. and Eder H. A.: Effects of high sucrose diets and 4-aminopyrazolopyrimidine on serum lipids and lipoproteins in the rat. J. lipid Res. 12 (1971) 596-603.

20. Kuroda M. K., Tanzawa Y., Tsujita Y. and Endo A.: Mechanism for elevation of hepatic cholesterol synthesis and serum cholesterol levels in Triton WR-1339. induced hyperlipidemia. Biochem. Biophys. Acta 489 (1977) 119-125.

21. Goldfarb S: Rapid increase in hepatic HMG. CoA reductase activity and in vivo cholesterol synthesis after Triton WR 1339 injection. J. lipid Res. 19 (1978) 489-494.

22. Ishikawa $T$. and Fidge N.: Changes in the concentration of plasma lipoproteins and apoproteins following the administration of Triton WR 1339 to rats. J. lipid Res. 20 (1979) 254-264.

23. Catt K. J., Dufau M. L. and Tsuruhara T.: Radioligand receptor assay of luteinizing hormone and chorionic gonadotropin. J. clin. Endocr. Metab. 34 (1972) 123-132.

24. Dufau M. L., Mandelson C. R. and Catt K. J.: A highly sensitive in vitro bioassay for luteinizing hormone and chorionic gonadotropin: testosterone production by dispersed Leydig cells. J. clin. Endocr. Metab. 39 (1974) 610-613.

25. Moyle W. R. and Ramachandran J.: Effect of LH on steroidogenesis and cyclic AMP accumulation in rat
Leydig cell preparation and mouse tumor Leydig cells. Endocrinology 93 (1973) 127-134.

26. Auletta F. J., Caldwell B. V. and Hamilton G. L.: Androgens: testosterone and dehydrotestosterone. In Methods of Hormone Radioimmunoassay (Edited by B. M. Jaffe and H. R. Behrman). Academic Press, New York (1979) pp. 359370.

27. Niswender G. D., Akbar A. M. and Nett T. M. Radioimmunoassay procedures for quantification of steroid hormones. In Hormones in Human Blood (Edited by H. N. Antoniades).Harvard University Press, Cambridge (1976) pp. 751-776.

28. Parlow A. F.: A rapid bioassay method for LH and factors stimulating LH secretion. Fed. Proc. 17 (1958) 402.

29. Menon M., Azhar S. and Menon K. M. J.: Evidence that danazol inhibits gonadotropin-induced ovarian steroidogenesis at a point distal to gonadotropinreceptor interaction and adenosine $3^{\prime}, 5^{\prime}$ cyclic monophosphate formation. Am. J. Obstet. Gynecol. 136 (1980) $524-530$.

30. Azhar S. and Menon K. M. J.: Receptor mediated gonadotropin action in the ovary. Action of cytoskeletal element-disrupting agents on gonadotropin induced steroidogenesis in rat luteal cells. Biochem. J. (In press).

31. Kawano A.. Gunaga K. P. and Menon K. M. J.: Stimulatory effect of gonado-tropin on the synthesis of adenosine $3^{\prime}: 5^{\prime}$-cyclic monophosphate and progesterone by suspensions of rat ovarian interstitial cells. Biochim. biophys. Acta 385 (1975) 88-100.

32. Sen K. K., Azhar S. and Menon K. M. J.: Receptormediated gonadotropin action in the ovary. Desensitization of gonadotropin binding sites, activation of adenosine $3^{\prime}: 5^{\prime}$-cyclic monophosphate-dependent protein kinase(s), and regulation of steroidogenesis in rat ovary. J. biol. Chem. 254 (1979) 5664-5671.

33. Burton K.: A study of conditions and mechanisms of the diphenylamine reaction for the colorimetric estimation of deoxyribonucleic acid. Biochem. J. 62 (1956) 315-323.

34. Zak B.: Total and free cholesterol. Stand. Methods Clin. Chem. 5 (1965) 79-89.

35. Brown M. S., Faust J. R. and Goldstein J. L.: Role of the low density lipoprotein receptor in regulating the content of free and esterified cholesterol in human fibroblasts. J. clin. Invest. 55 (1975) 783-793.

36. Glick D., Fell B. F. and Sjolin K. E.: Spectrophotometric determination of nanogram amounts of total cholesterol in microgram quantities of tissue or microliter volumes of serum. Anal. Chem. 36 (1964) 1119-1121

37. Havel R. J., Eder H. A. and Bragdon J. G.: The distribution and chemical composition of ultracentrifugally separated lipoproteins in human serum. $J$. clin. Invest. 34 (1955) 1345-1353.

38. Lowry O. H., Rosebrough N. J., Farr A. L. and Randall R. J.: Protein determination with the Folin Phenol reagent. J. biol. Chem. 193 (1951) 265-275.

39. Markwell M. A. K., Hass S. M., Bieber L. L. and Tolbert N. E.: A modification of the Lowry procedure to simplify protein determination in membrane and lipo. protein samples. Anal. Biochem. 87 (1978) 206-210.

40. Balasubramaniniam S., Goldstein J. L., Faust J. R. and Brown M. S.: Regulation of cholesterol synthesis in rat adrenal gland through coordinate control of 3-hydroxy-3-methyl glutoryl coenzyme $A$ synthase and reductase activities. Proc. natn. Acad. Sci. U.S.A. 73 (1976) 2564-2568.

41. Mendelson C., Dufau M. and Catt K.: Gonadotropin binding and stimulation of cyclic adenosine $3^{\prime}: 5^{\prime}$-monophosphate and testosterone production in isolated Leydig cells. J. biol. Chem. 250 (1975) 8818-8823. 
42. Gerson T., Shorland F. B. and Dunckley G. G.: The effect of $\beta$-sitosterol on the metabolism of cholesterol and lipids in rats on a diet low in fat. Biochem. J. 92 (1964) 385-390.

43. Morris M. D. and Chaikoff I. L.: The origin of cholesterol in liver, small intestine, adrenal gland, and testis of rat: Dietary vs endogenous contributions. $J$. biol. Chem. 234 (1959) 1095-1097.

44. Chen Y-D. I., Kraemer F. B. and Reaven G. M.: Identification of specific high density lipoprotein-binding sites in rat testis and regulation of binding by human chorionic gonadotropin. J. biol. Chem. 255 (1980) 9162-1967.

45. Schreiber J. R., Hsueh A. J. W., Weinstein D. B. and Erickson G. F.: Plasma lipoproteins stimulate progestin production by rat ovarian granulosa cells cultured in serum free medium. $J$. steroid Biochem. 13 (1980) $1009-1014$.

46. Andersen J. M. and Dietschy J. M.: Regulation of sterol synthesis in 16 tissue of rat. Effect of diurnal light eycling, forting, stress, manipulation of enterohepatic circulation and administration of chylomicrons and triton. J. biol. Chem. 252 (1977) 3646-3651.

47. Otway S. and Robinson D. S.: The use of a nonionic detergent (Triton WR 1339) to determine rates of triglyceride entry into the circulation of the rat under different physiological conditions. J. Physiol. 190 (1967) 321-332.

48. Schurr P. E., Schultz J. R. and Parkinson T. M.: Triton induced hyperlipidemia in rats as an animal model for screening hyperlipidemic drugs. Lipids 7 (1972) 68.74 .

49. Zilversmit D. B., Hughes L. B. and Remington $M$. Hypolipidemic effect of pregnancy in the rabbit. J. lipid Res. 13 (1972) 750-756.

50. Klauda H. C. and Zilversmit D. B.: Influx of cholesterol into plasma in rabbits with fasting hyperbetalipoproteinemia. J. lipid Res. 15 (1974) 593-601.

51. Kovanen P. T., Goldstein J. L. and Brown M. S.: High levels of 3-hydroxy-3-methylglutaryl coenzyme A reductase activity and cholesterol synthesis in the ovary of the pregnant rabbit. J. biol. Chem. 253 (1978) $5126-5132$.

52. Illingworth D. R., Whipple L. E. and Portman O. W. Metabolism of lipoproteins in nonhuman primates. Reduced secretion of very low density lipoproteins in squirrel monkeys with diet induced hypercholesterolemia. Atherosclerosis 22 (1975) 325-334. 